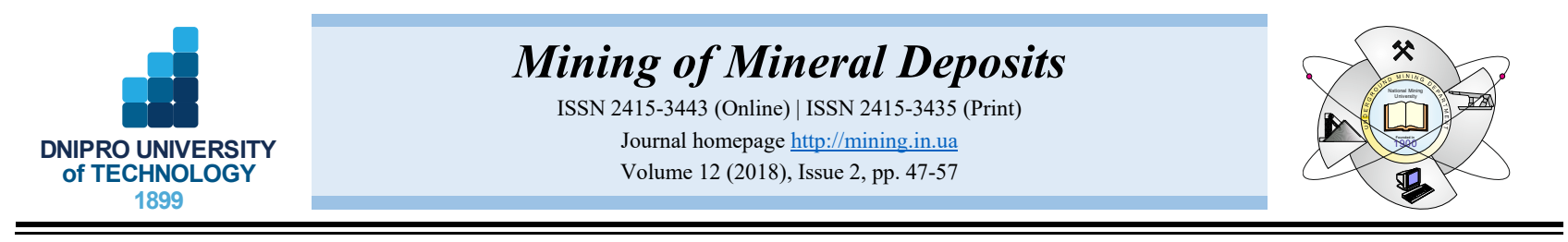

UDC 622.271 .332

https://doi.org/10.15407/mining12.02.047

\title{
EVALUATION OF OPEN PIT SLOPE STABILITY USING VARIOUS SLOPE ANGLES AND ELEMENT TYPES
}

\author{
W.R. Abdellah ${ }^{1 *}$, M.M. Beblawy ${ }^{1}$, M.T. Mohamed ${ }^{1}$ \\ ${ }^{1}$ University of Assiut, Assiut, Egypt \\ *Corresponding author: e-mail wre544@gmail.com, tel. +201222300549
}

\begin{abstract}
Purpose. The objective of this study is to demonstrate a method to select the optimal slope angle related to three principal factors: safety, productivity and mining costs. Also, it aims to investigate the accuracy of numerical analysis using different element types and order.

Methods. Series of two-dimensional elasto-plastic finite-element models has been constructed at various slope angles (e.g. $40^{\circ}, 45^{\circ}, 50^{\circ}, 55^{\circ}, 60^{\circ}, 65^{\circ}$, and $70^{\circ}$ ) and different element types (e.g. 3-noded triangle $\left(T_{3}\right), 6$-noded triangle $\left(T_{6}\right)$, 4-noded quadrilateral $\left(Q_{4}\right)$ and 8-noded quadrilateral $\left(Q_{8}\right)$. The results are presented, discussed and compared at various slope angles and element types in terms of critical strength reduction factor (CSRF) or its equivalent factor of safety (FOS), total rock slope displacement, mine production and mining costs.

Findings. The results reveal that, the mine productivity increases as slope angle increases, however, slope stability deteriorates. Alternatively, the factor of safety (FOS) decreases as slope angle becomes steeper (e.g. minimum factor of safety is obtained at highest steep angle of $70^{\circ}$ ). Despite of the increasing in computation time, the analysis shows that, the accuracy of the modelling increases when adopting high-order element types (e.g. 8-noded quadrilateral and 6-noded triangle elements).
\end{abstract}

Originality. This study provides a methodology for the application of the numerical modelling methods on open pit mine. As a result, the mine planners will be able to know ahead of time the optimal slope angle with respect to safety, production and mining costs.

Practical implications. This study sheds light on the usefulness of adopting numerical modelling analysis in the feasibility studies to determine and compare mining costs against safety and slope angle.

Keywords: slope stability, open pit mine, critical strength reduction factor (CSRF), open pit excavation sequence, finite-element method (FEM), numerical modelling, strength criterion

\section{INTRODUCTION}

Safety and productivity are the keys for the success of open pit mine extraction. The stripping ratio should be minimized to decrease the overall mining costs. Slope instability is expensive and usually has negative impacts on the mine profitability (Kumar \& Parkash, 2015). Therefore, it is imperative to design slope angle that maintains open pit compete. Stability of open pit is governed by the slope geometry (e.g. height and slope angle), presence of ground water and characteristics of rock mass (e.g. quality, strength, presence of geological features such as joints, faults, etc.).

Geological features determine the pattern of slope failure and its mechanism (e.g., planar, wedge, toppling and/or circular failure) (Hoek \& Bray, 1981; Bye \& Bell, 2001; Hossain, 2011; Marndi, 2011; Fleurisson \& Co- jean, 2014; Kumar \& Parkash, 2015). However, these factors are always unique to a particular site, therefore, it is difficult to generalize the slope angle for all open pit mines (e.g. due to the heterogeneity/variability of rock mass properties) (Jaeger, 1971; Goodman, 1989; Wyllie \& Mah, 2004; Li, Merifield, \& Lyamin, 2011).

Open pit mine may extend to hundreds of meters (e.g. South Africa Sandsloot is; located at an elevation of $1100 \mathrm{~m}$, the largest open pit mining platinum in the world, about $1500 \mathrm{~m}$ long, $800 \mathrm{~m}$ wide and projected depth of $325 \mathrm{~m}$ ). Consequently, millions of dollars may be lost if inappropriate overall slope angle is designed. Slope angle affects the stripping ratio (e.g. ratio of tonnage or volume of overburden to be removed-to-tonnage or volume of ore to be extracted) and hence, overall mine profitability (Bye \& Bell, 2001; Marndi, 2011). Alternatively, the higher the stripping ratio, the more expensive

(C) 2018. W.R. Abdellah, M.M. Beblawy, M.T. Mohamed. Published by the Dnipro University of Technology on behalf of Mining of Mineral Deposits. This is an Open Access article distributed under the terms of the Creative Commons Attribution License (http://creativecommons.org/licenses/by/4.0/), which permits unrestricted reuse, distribution, and reproduction in any medium, provided the original work is properly cited. 
mining and the less profit is then earned. Reducing of the stripping ratio (e.g., less waste rock to be removed) requires keeping the ultimate slope angle as steep as possible (e.g., increase ore recovery). But, the steeper slope angle the more instability issues are encountered. Thus, the successful design of open pit slope has to combine stability, productivity and mining costs altogether.

Accurate information is required about geology, site characteristics (e.g. slope geometry, rock mass properties, ground water conditions and associated discontinuities, etc.). The final design of optimal slope angle of open pit is controlled not only by ore grade distribution and operational cost, but also by the overall rock mass properties. So, it is recommended that, the potential for failure should be incorporated into the ultimate open pit design. Thus, it helps, in advance, to know temporally (e.g., when) and spatially (e.g., where) actions have to be taken (Brahma, 2009).

\section{METHOD OF ANALYSIS}

Several methods have been existed to assess open pit slope stability such as method of limit equilibrium, analytical and numerical modelling methods. The limit equilibrium method (LEM) is widely used to estimate the FOS. Such method assumes the shape, location of failure and horizontal forces act upon the sides of the slides and their directions. It is developed and analyzed based on the actual case histories (Ching \& Fredlund, 1983; Krahn, 2003; Singh, 2006; Krahn, 2007; Chatterjee \& Elkadi, 2012; Berisavljević, Berisavljević, Čebašek, \& Rakić, 2015). The FOS is estimated as per Equation (1):

$$
F S=\frac{\tau_{f}}{\tau_{m}},
$$

where:

$$
\begin{aligned}
& \tau_{f}-\text { the actual shear strength of rock mass; } \\
& \tau_{f}-\text { the mean shear stress on the assumed surface of }
\end{aligned}
$$
failure mobilized to maintain body in equilibrium.

As introduced in Equation (1), the FOS is defined as the ratio of rock shear strength at failure to the mobilized shear stress on the surface of failure. LEM has shortcomings such as it does not consider the stress-strain behaviour of rock mass when estimating the FOS. In addition, it uses trial and errors to estimate the pattern of critical slip surface (Roosta, Sadaghiani, \& Pak, 2005; Hamade, 2013; Berisavljević, Berisavljević, Čebašek, \& Rakić, 2015). For more details about LEM, the reader is directed to work of Morgenstern \& Price (1967) and Fredlund \& Krahn (1977).

Numerical methods (e.g., finite-element methods (FEMs), finite-difference methods (FDMs) and/or discrete-element methods (DEMs)) are powerful tools, (e.g., they efficiently handle complex mine geometry), which provide an approximate solutions to the boundary value problems for partial differential equations (Hammah, Yacoub, \& Corkum, 2005; Maleki, Mahyar, \& Meshkabadi, 2011; Soren, Budi, \& Sen 2014; Berisavljević, Berisavljević, Čebašek, \& Rakić, 2015). They satisfy all requirements that have to be met for a complete solution to slope stability problems. The behaviour of the material can be modelled with various constitutive equations and numerical simulation techniques, e.g. perfect elasto-plastic analysis with Mohr-Coulomb failure criterion, creep deformation with Burger's model and jointed rock mass with interface elements (Brinkgreve \& Bakker, 1991; Potts \& Zdravkovic, 1999). Also, hybrid techniques have widely become acceptable in the assessment of rock slopes. These tools combine LEM and FEMs ground water flow and stress analysis (GEO-SLOPE..., 2010; Marndi, 2011; RocScience..., 2011). This study does not represent a real case study. But, it uses representative geological properties (e.g. they are obtained from Jiang \& Cao, 2013) and general open pit mine geological features. Also, it is conducted to demonstrate a method to demonstrate an optimal slope angle while maintaining FOS, maximize mine productivity and minimize mining costs. For such purpose, series of models have been built using Rock-Science, $\mathrm{RS}^{2 \mathrm{D}}$ (RocScience..., 2016), finite-element code at various slope angles and different element types. The slope stability is evaluated using CSRF or its equivalent FOS, maximum shear strain and total displacement. The following section briefly presents the different element types and their orders that are adopted in this study.

\section{ELEMENT TYPES/ORDERS}

When modelling a structure/orebody, its geometry is discretized into small pieces known as "elements". Such elements could be one-, two- or three-dimensional. Alternatively, there are three types of elements namely: line, surface/area and solid/volume elements. Each element is connected to another through the nodes using shape function. The latter, shape function, defines the distribution of the displacement across the elements and it varies according to element type and order. The demonstration of the shape function for each element type and its mathematical formula is beyond the objective of this study. In this study, two-dimensional triangular and quadrilateral element types with different orders, as depicted in Figure 1, have been adopted to investigate their influence on the accuracy of the numerical results. (a)

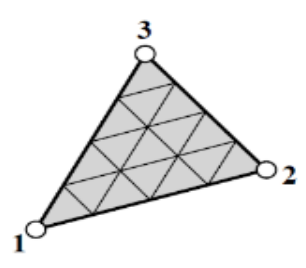

(c)

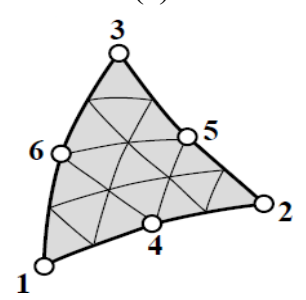

(b)

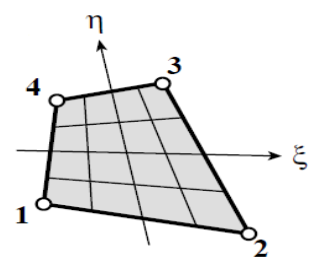

(d)

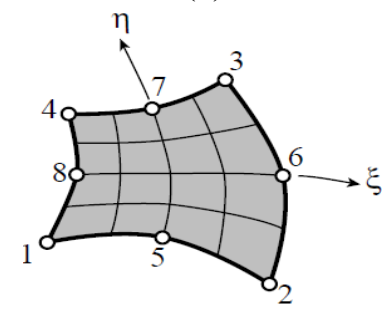

Figure 1. The geometry, type and order of the twodimensional finite-elements employed in this analysis: (a) 3-node triangular element; (b) 4-node quadrilateral element; (c) 6-node triangular element; (d) 8-node quadrilateral element (Norton, 2006; Boeraeve, 2010; Neupane, 2014) 


\section{NUMERICAL MODELLING ANALYSIS}

In this analysis, Mohr-Coulomb yielding-based criterion has been adopted using rock-soil, $\mathrm{RS}^{2 \mathrm{D}}$, software (RocScience..., 2016). Table 1 lists the geomechanical properties of rock mass which are used as model input parameters (Jiang \& Cao, 2013). Modelling set up and boundary conditions are presented in section 4.1. The results of numerical modelling analysis are introduced and discussed in section 5. The stability of rock slope is evaluated in terms of CSRF or its equivalent FOS, maximum shear strain and total displacement. Then, ore productivity and its corresponding extraction costs at various slope angles have been estimated, presented and discussed in section 5.4 .

Table 1. Geomechanical properties of open pit rock mass used in the analysis (Jiang \& Cao, 2013)

\begin{tabular}{lccc}
\hline \multicolumn{1}{c}{ Rock mass property } & $\begin{array}{c}\text { Hanging wall } \\
\text { (Meta- } \\
\text { sediment) }\end{array}$ & $\begin{array}{c}\text { Orebody } \\
\text { (Copper- } \\
\text { nickel) }\end{array}$ & $\begin{array}{c}\text { Footwall } \\
\text { (Green- } \\
\text { stone) }\end{array}$ \\
\hline Density, MN $/ \mathrm{m}^{3}$ & 0.0261 & 0.0251 & 0.0273 \\
$U C S, \mathrm{MPa}$ & 73.4 & 40.3 & 93.0 \\
$E, \mathrm{GPa}$ & 44.7 & 57.0 & 61.2 \\
Poisson's ratio, $v$ & 0.17 & 0.20 & 0.19 \\
Cohesion, $C, \mathrm{MPa}$ & 0.757 & 0.257 & 0.245 \\
Tensile strength, & 7.34 & 4.03 & 9.30 \\
$\sigma_{t}, \mathrm{MPa}$ & 49 & 50 & 48 \\
Friction angle, $\phi$, deg & 0 & 0 & 0 \\
Dilation angle, $\Psi$, deg & 0 & & \\
\hline
\end{tabular}

\subsection{Modelling set up}

Figure $2 \mathrm{a}-\mathrm{d}$ depicts the geometry and boundary conditions of the reference model at overall slope angle of $70^{\circ}$ and several element types of different orders. The dimensions of the model are $300 \times 120 \mathrm{~m}$ (e.g. width $\times$ height). The orebody comprises of Copper-nickel and the host rock mass consists of Greenstone (e.g. footwall) and Metasediment (e.g. hanging wall). The bottom of the model is fixed in both $X$ - \& $Y$-directions, while the vertical boundaries are fixed only in $X$-direction. The upper boundary (e.g., ground surface) of the model is simulated as free surface.

\section{RESULTS AND DISCUSSION}

As stated before, series of two-dimensional elastoplastic finite-elements models have been developed at various ultimate slope angles (e.g. $40^{\circ}, 45^{\circ}, 50^{\circ}, 55^{\circ}$, $60^{\circ}, 65^{\circ}$ and $70^{\circ}$ ) and different element types/order to examine their effect on the slope stability of open pit mine, the amounts of ore to be extracted and the corresponding mining costs. Moreover, several element types of different orders have been employed to investigate their influence on the accuracy of numerical results. The numerical modelling results of open pit at overall slope angle of $70^{\circ}$ are presented, discussed and compared at different element types/orders in terms of CSRF or its equivalent FOS, maximum shear strain and total displacement of rock slope.

\subsection{Critical strength reduction factor (CSRF)}

CSRF refers to the value by which strength properties of rock mass (e.g., cohesion \& friction angle) have to be reduced to reach failure. Mathematically $S R F$ is expressed as follows, Equation (2):

$S R F=\frac{\tan \varphi}{\tan \varphi_{f}}=\frac{C}{C_{f}}$,

where:

$S R F$ - strength reduction factor, which is used to define the value of rock mass strength parameters at a given stage of the analysis;

$C$ and $\varphi$-the soil/rock mass shear strength input values/parameters;

$C_{f}$ and $\varphi_{f}-$ the soil/rock mass shear strength reduced or mobilized values used in the analysis.

It is worthy to mention that, $S R F$ is set to 1.0 at the beginning of calculations (e.g., rock mass strength properties are set to their input values, cohesion \& friction angle). While in case of failure the SRF, which is defined by Equation (2), corresponds to the FOS aforementioned in Equation(1). Figure $3 \mathrm{a}-\mathrm{d}$ shows the CSRF for rock slope of open pit mine at overall slope angle of $70^{\circ}$ and different element types. The CSRF varies according to element type/order for the same slope angle. For instance, the highest CSRF (e.g. $\mathrm{CSRF}=3.40)$ is obtained when using 4-noded quadrilateral element (e.g. $Q_{4}$ ); whereas, the least CSRF (e.g. $\mathrm{CSRF}=1.60)$ is obtained with 8-noded quadrilateral element (e.g. $Q_{8}$ ).

The CSRF or its equivalent FOS at different element types and various slope angles, is shown in Figure 4. Table 2 lists the values of CSRF or its equivalent FOS and maximum shear strain at different slope angles.

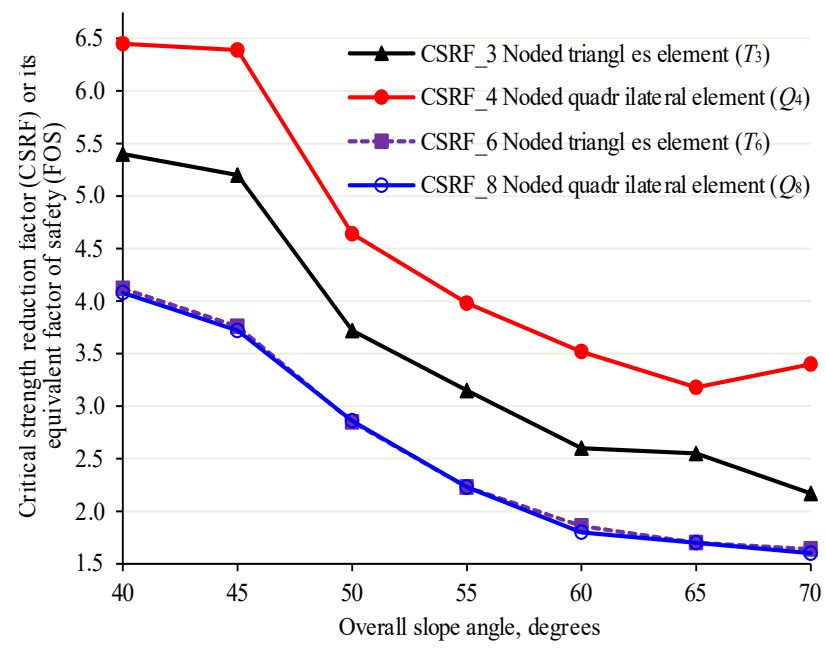

Figure 4. CSRF at various open pit slope angles and different element types

As illustrated in Figure 4, the FOS decreases as slope angle becomes steeper. Alternatively, the minimum factor of safety is obtained at highest steep angle (e.g. $70^{\circ}$ ) for all element types/order. 
(a)

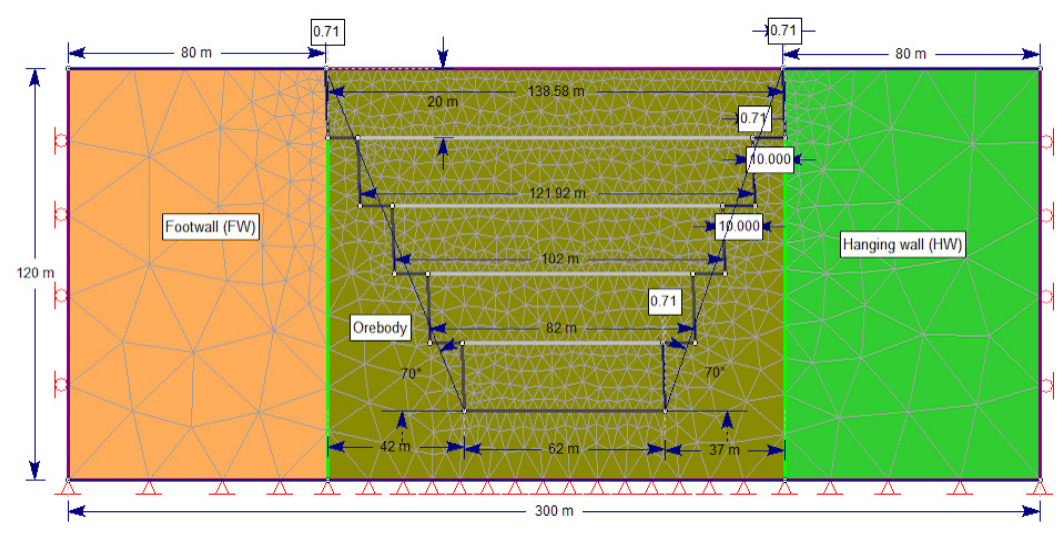

(b)

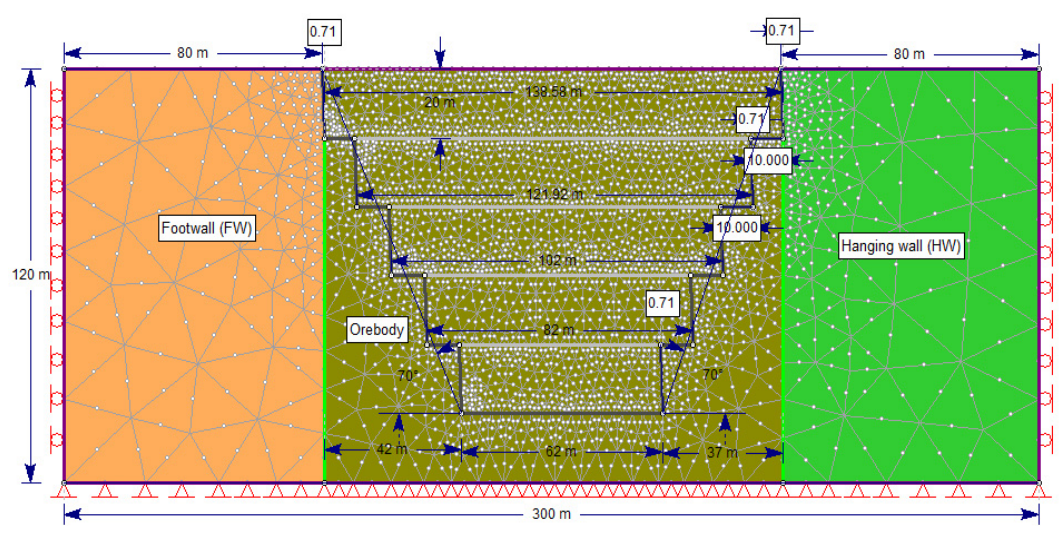

(c)

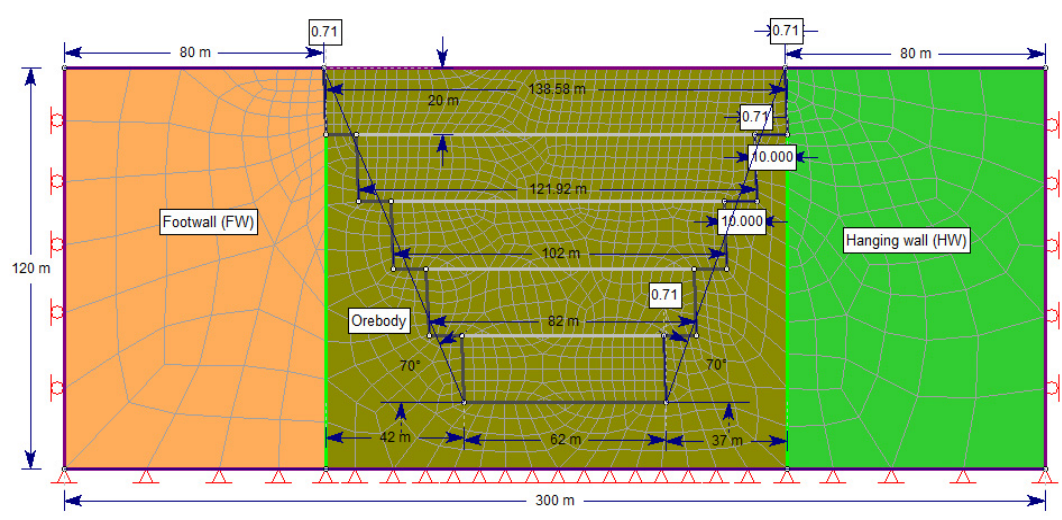

(d)

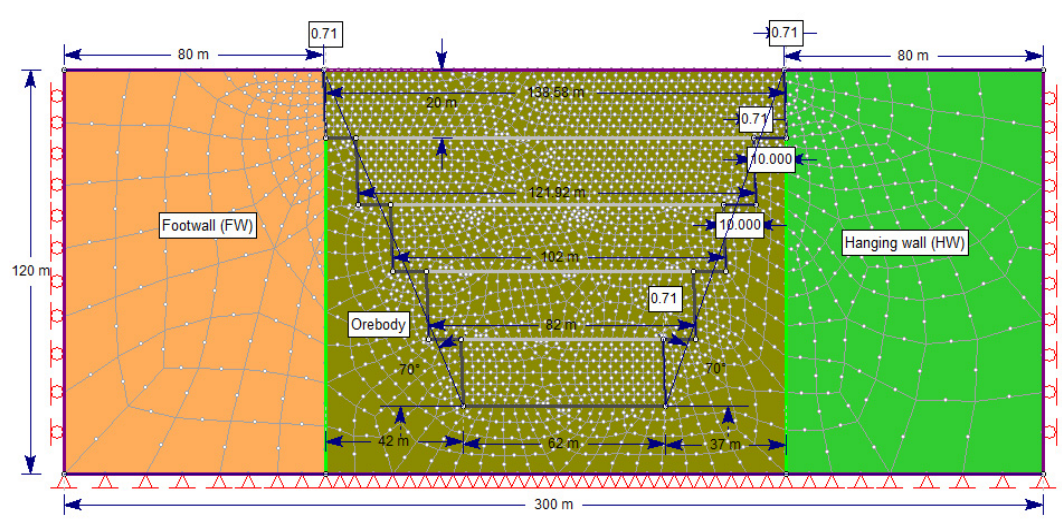

Figure 2. Boundary conditions of the reference model at slope angle of $70^{\circ}$ and different element types/order: (a) 3-noded triangle element; (b) 6-noded triangle element; (c) 4-noded quadrilateral element; (d) 8-noded quadrilateral element 
(a)
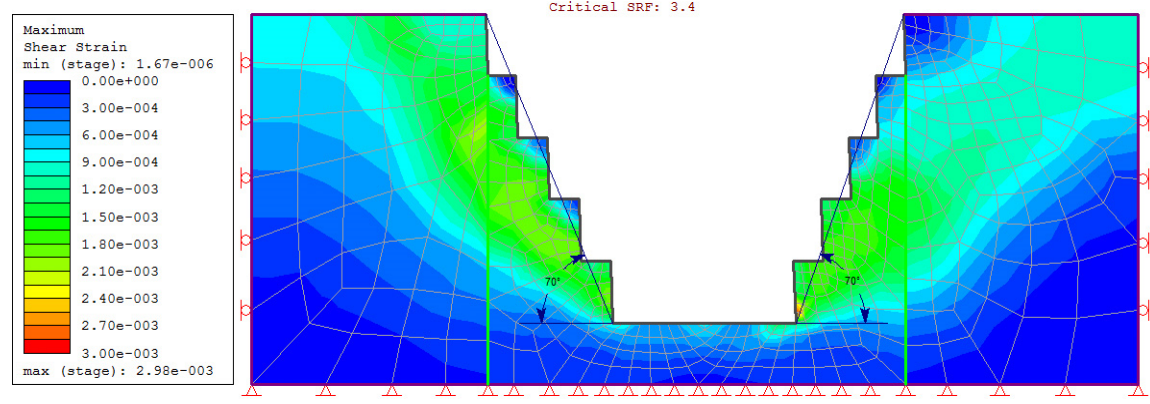

(b)
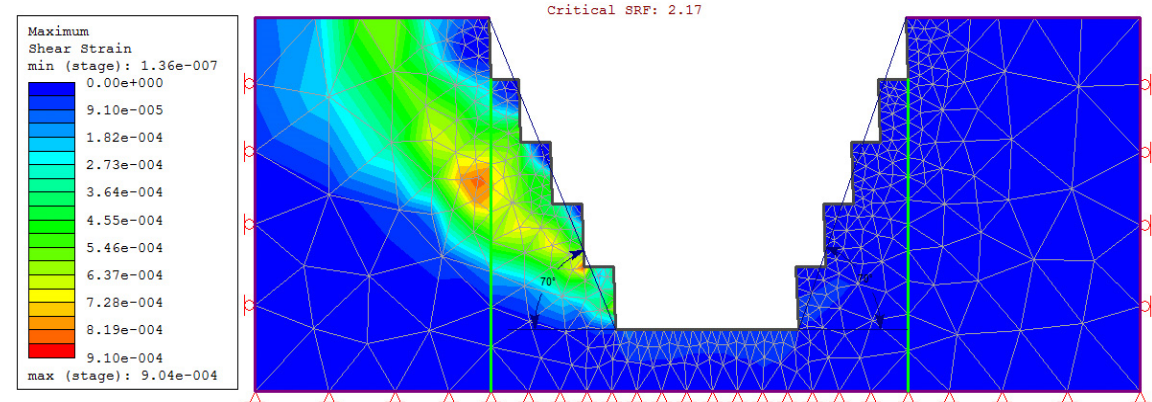

(c)
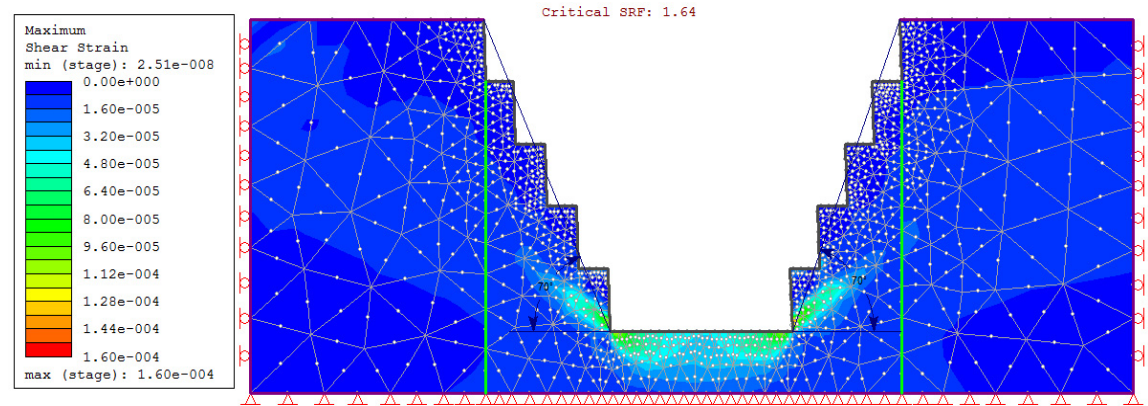

(d)
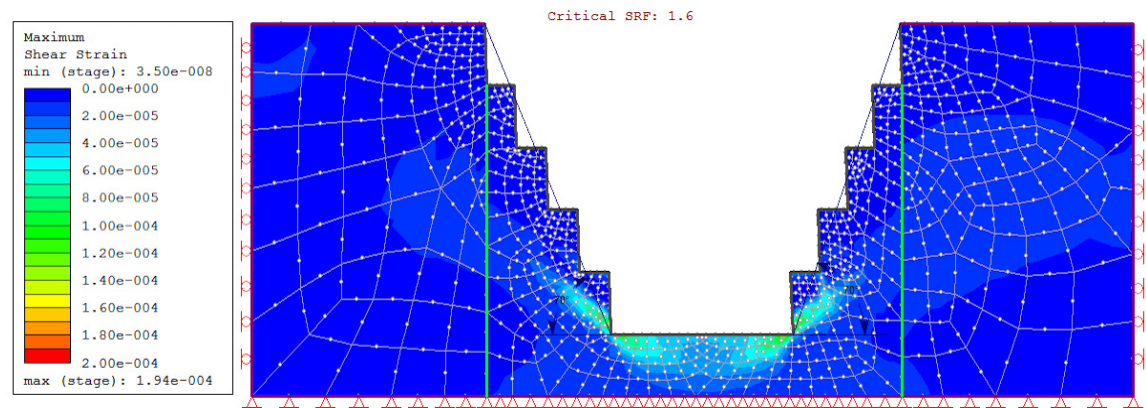

Figure 3. Maximum shear strain at slope angle of $70^{\circ}$ : (a) 4-noded quadrilateral element ( $\left.Q_{4}\right)$; (b) 3-noded triangle element ( $\left.T_{3}\right)$; (c) 6-noded triangle element $\left(T_{6}\right)$; (d) 8-noded quadrilateral element $\left(Q_{8}\right)$

Table 2. Strength reduction factor and factor of safety and shear strain at various slope angles and different element types

\begin{tabular}{ccccccccc}
\hline Overall slope & \multicolumn{4}{c}{ CSRF or FOS } & \multicolumn{5}{c}{ Maximum shear strain } \\
\cline { 2 - 9 } angle, $(\alpha)$, deg. & $T_{3}$ & $T_{6}$ & $Q_{4}$ & $Q_{8}$ & $T_{3}$ & $T_{6}$ & $Q_{4}$ & $Q_{8}$ \\
\hline 40 & 5.40 & 4.12 & 6.45 & 4.08 & 0.000967 & 0.0001030 & 0.001310 & 0.0001900 \\
45 & 5.20 & 3.76 & 6.39 & 3.72 & 0.000432 & 0.0000803 & 0.000891 & 0.0000998 \\
50 & 3.72 & 2.85 & 4.64 & 2.86 & 0.000486 & 0.0001290 & 0.001270 & 0.0001430 \\
55 & 3.15 & 2.23 & 3.98 & 2.23 & 0.001370 & 0.0001480 & 0.002550 & 0.0001480 \\
60 & 2.60 & 1.86 & 3.52 & 1.80 & 0.001220 & 0.0001800 & 0.001610 & 0.0002330 \\
65 & 2.55 & 1.70 & 3.18 & 1.70 & 0.001700 & 0.0001750 & 0.001450 & 0.0002090 \\
70 & 2.17 & 1.64 & 3.40 & 1.60 & 0.000904 & 0.0001600 & 0.002980 & 0.0001940 \\
\hline
\end{tabular}




\subsection{Maximum shear strain}

Figure 5 displays the maximum shear strain at various overall slope angles and different element types (e.g. also see Table 2). It can be shown that, maximum shear strain increases as overall slope angle increases and element order decreases. Therefore, the more stable slope is found at small overall slope angle (e.g. $40^{\circ}$ ) and highorder element types (e.g., $T_{6}$ and $Q_{8}$ ).

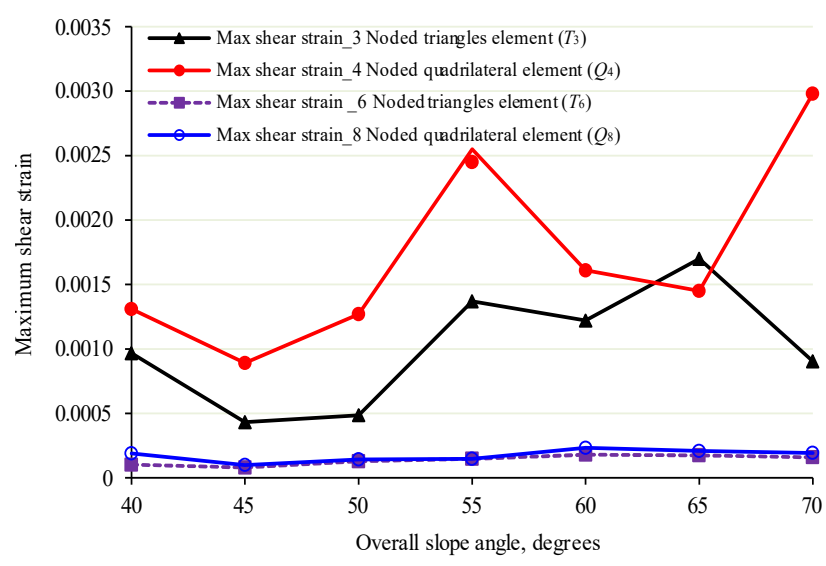

Figure 5. Maximum shear strain at various slope angles and different element types/order

\subsection{Total rock slope displacement}

Displacement may be adopted as an indicator to measure the movement/deformation of the rock mass. The slope stability deteriorates as rock mass deformation increases. Figure 6 illustrates the total displacement occurs at various ultimate slope angles and different element types/order.

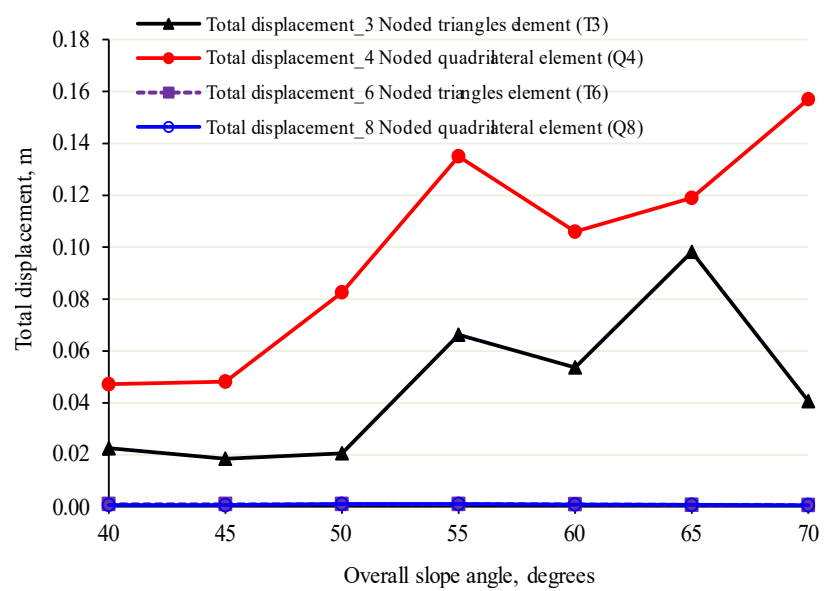

Figure 6. Total displacement occurs at various slope angles and different element types

The results show that, the rock slope displacement increases as slope angle increases and element types/order decreases. The total displacements, at overall slope angle of $70^{\circ}$, are $0.175,0.0448,0.0067$ and $0.0006 \mathrm{~m}$ when adopting element types/order 4-noded, 3-noded, 6-noded and 8-noded respectively. Table 3 lists the total displacements obtained at various slope angles and different element types/order. Figure 6 depicts the total displacements against the ultimate slope angles for each element type.
Table 3. Total displacement at different slope angles and various element types

\begin{tabular}{ccccc}
\hline \multirow{2}{*}{$\begin{array}{c}\text { Overall slope } \\
\text { angle, }(\alpha), \text { deg. }\end{array}$} & \multicolumn{4}{c}{ Total displacement, $\mathrm{m}$} \\
\cline { 2 - 5 } & $T_{3}$ & $T_{6}$ & $Q_{4}$ & $Q_{8}$ \\
\hline 40 & 0.0226 & 0.001000 & 0.0472 & 0.000700 \\
45 & 0.0185 & 0.001010 & 0.0482 & 0.000605 \\
50 & 0.0206 & 0.001010 & 0.0826 & 0.001020 \\
55 & 0.0663 & 0.001080 & 0.1350 & 0.001090 \\
60 & 0.0537 & 0.000955 & 0.1060 & 0.000850 \\
65 & 0.0982 & 0.000736 & 0.1190 & 0.000727 \\
70 & 0.0407 & 0.000664 & 0.1570 & 0.000594 \\
\hline
\end{tabular}

\subsection{Tonnage of extracted ore and mining costs}

The tonnage of ore to be extracted and its associated mining cost are estimated at different slope angles. It is noteworthy to mention that, the mining costs should include both cost of overburden removal and cost of ore extraction. Generally, the cost of overburden removal decreases as slope angle increases and vice versa. However, when slope angle becomes steep, the slope stability deteriorates (e.g. factor of safety decreases).

Alternatively, low slope angles result in higher factor of safety, but larger costs than steep slope angles. In this study, for simplicity, only the cost of ore extraction is considered (e.g. cost of removal of overburden is not taken into account in addition to costs of machines, transportation, mine operators, blasting and explosive, drilling, milling, concentration, storage, etc.). Figure $7 \mathrm{a}-\mathrm{g}$ gives the dimensions of expected ore to be extracted at various slope angles.

The analysis shows that, the expected amount of ore to be mined out is directly proportional to slope angle. The highest tonnage of ore will be obtained at slope angle of $70^{\circ}$ (e.g. about 0.02560451 million tons and its extraction cost is about $\mathrm{M} \$ 0.05863)$. The calculation methodology dimensions and boundaries of amounts ore to be extracted at different slope angles and their corresponding operating costs are given at the end of this manuscript (Table 4, Appendix A). Also, Figure 8 depicts the estimated total tonnages of excavated ore and their corresponding costs at different rock slope angles. It can be shown that, the ore productivity and its mining cost increase as slope angle increases.

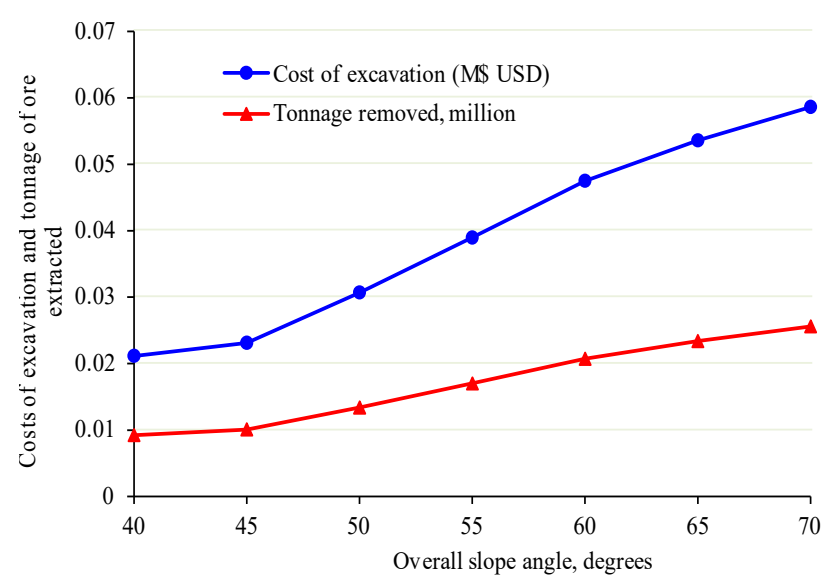

Figure 8. Expected amounts of ore to be extracted and their extraction costs at various slope angles 
(a)

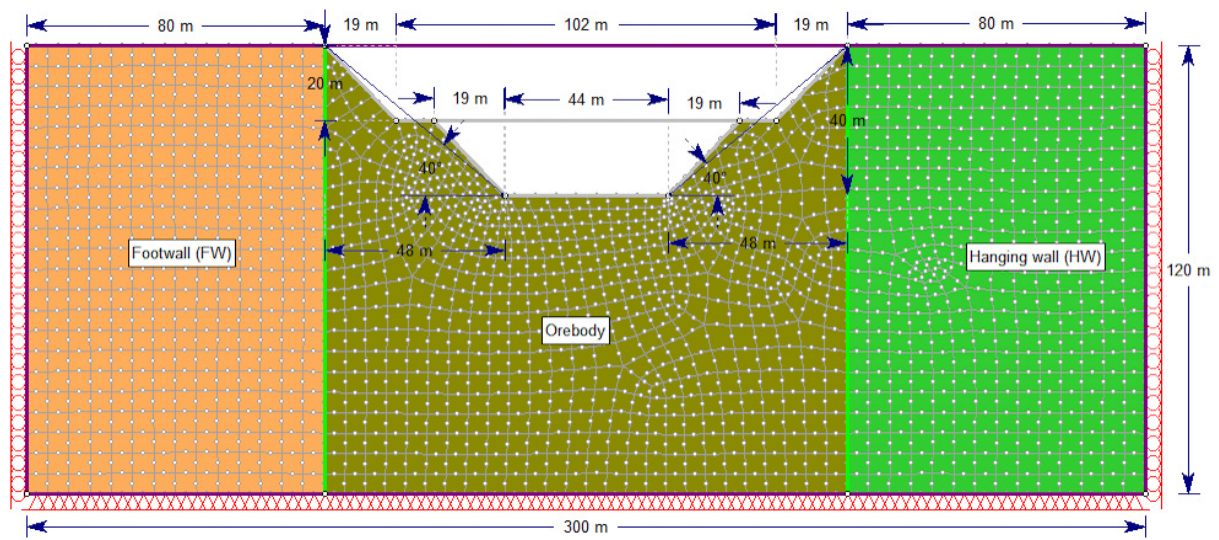

(b)

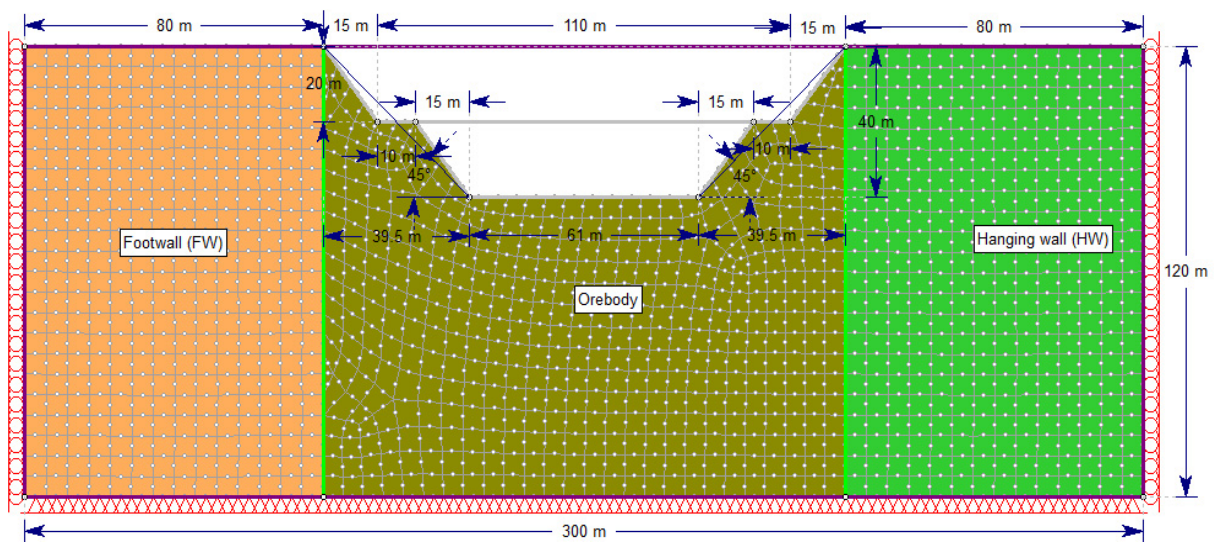

(c)

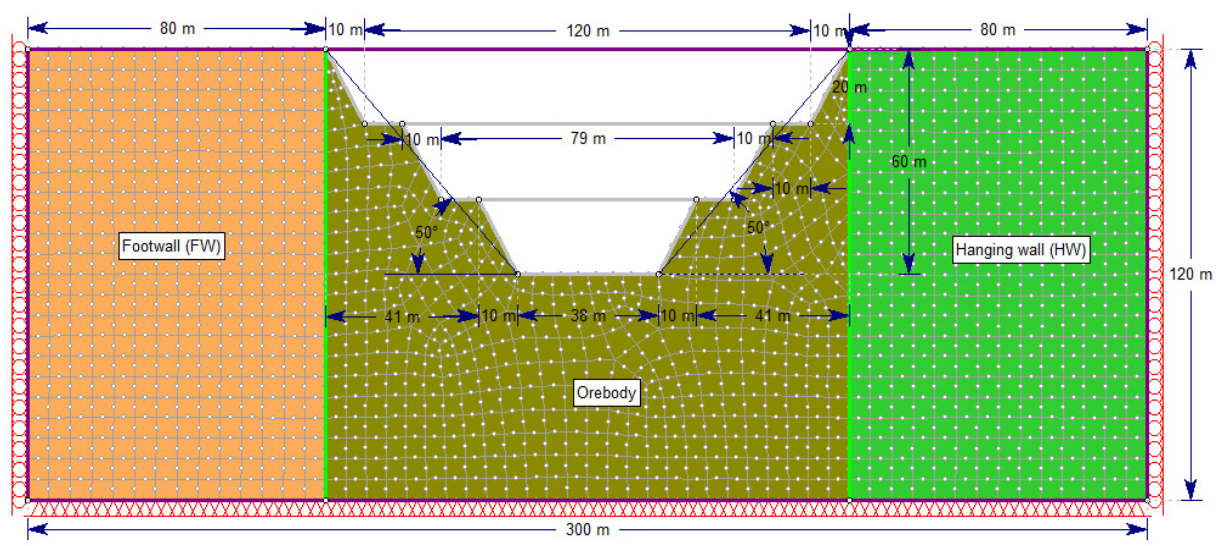

(d)

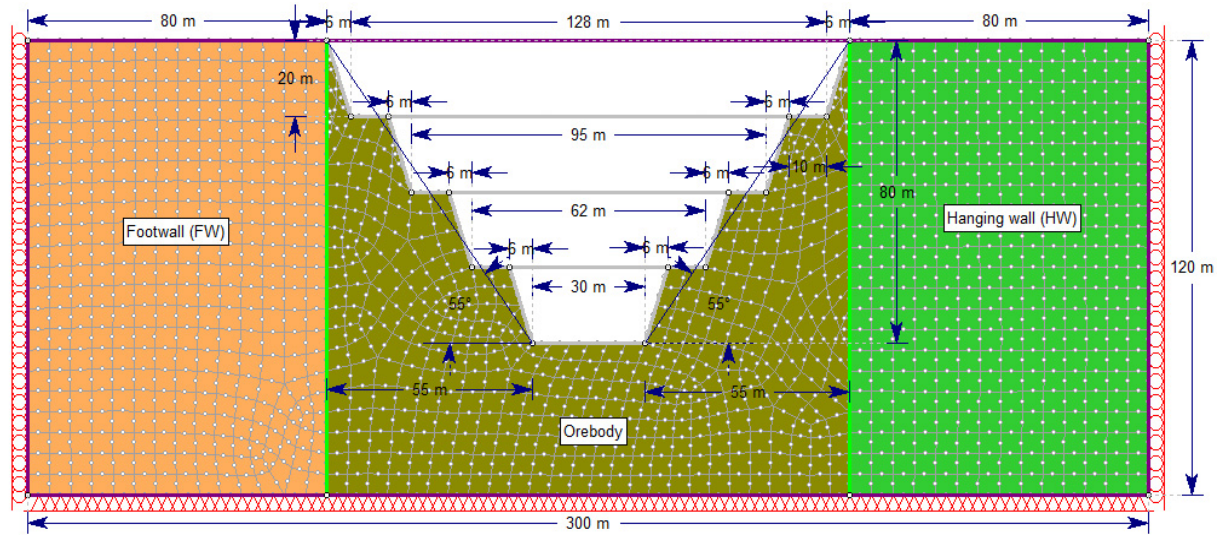


(e)

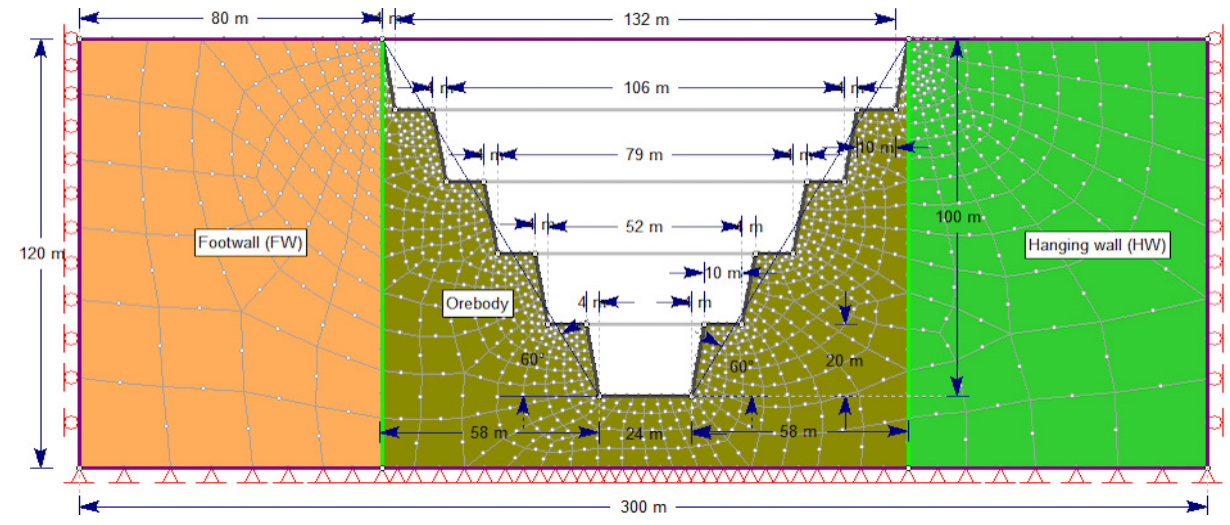

(f)

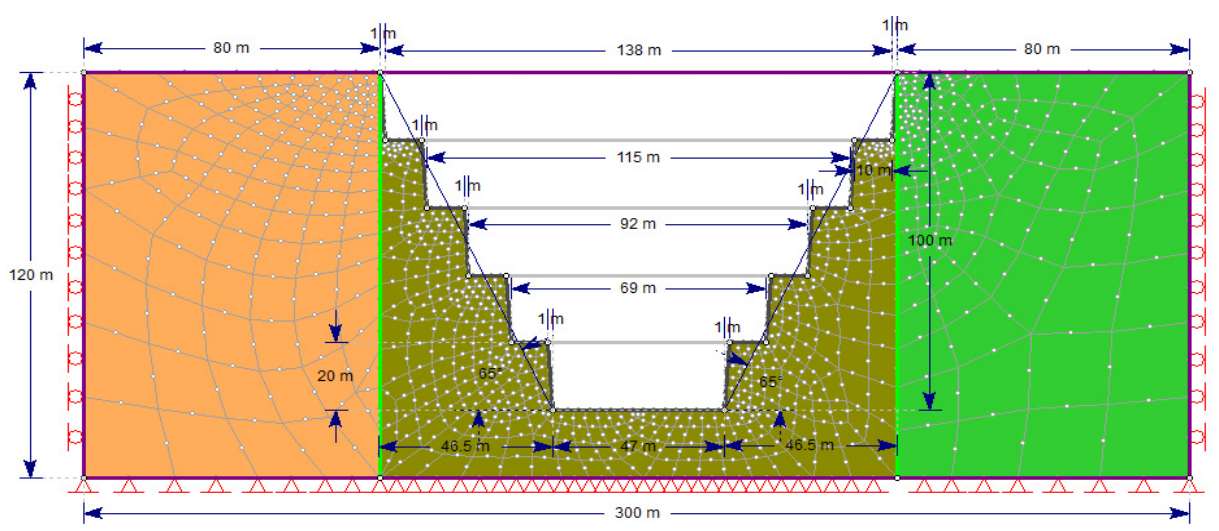

(g)

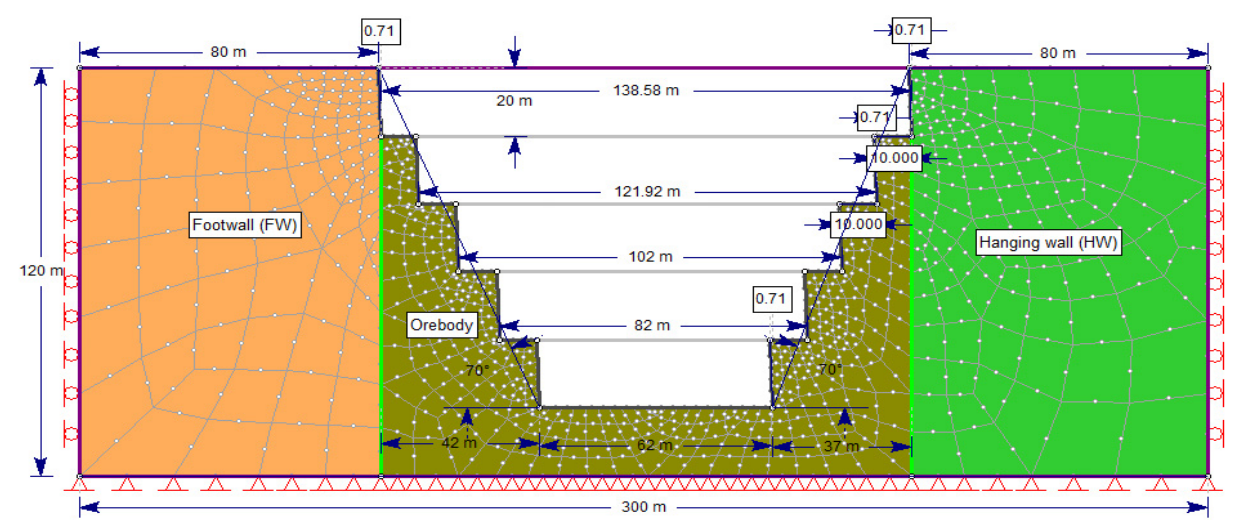

Figure 7. Dimensions of expected ore to be extracted at various slope angles: (a) $40^{\circ}$; (b) $45^{\circ}$; (c) $50^{\circ}$; (d) $55^{\circ}$; (e) $60^{\circ}$; (f) $65^{\circ}$; (g) $70^{\circ}$

\section{CONCLUSIONS}

Stability of slope is the major concern in open pit mines. Otherwise, slope instability leads to hazards to personnel, machinery and loss of mine profitability. The Overall slope angle has crucial impact on the stability of open pit mine and therefore, its productivity. To maximize the productivity of open pit, the ultimate slope angle should be designed as steep as possible. However, the FOS decreases as slope angle becomes steeper.

In this study, numerical modelling analysis has been conducted to propose a methodology to select the optimal slope angle based on three major factors namely: safety, productivity and costs. Also, the study aims to investigate the effect of different types/order on the accuracy of the modelling results. The results reveal that, as slope angle increases the stability of open pit deteriorates (e.g. factor of safety decreases). Therefore, the better stability is obtained at low slope angle. In addition to, the expected total amount of ore to be excavated is increased as slope angle becomes steep. Furthermore, the analysis shows that, the mining cost increases as slope angle increases. However, this cost does not include the cost of removal of overburden, mine machinery, operators, drilling, blasting, transportation, oil, milling and crushing, etc. Generally, the cost of removal of overburden decreases as slope angle increases. Despite of the computation time, the results show that, the accuracy of the numerical analysis increases when employing high order element type (e.g. 8-noded quadrilateral and 6-noded triangle elements). 


\section{APPENDIX A}

Table 4. Tonnage of ore to be excavated and its assumed corresponding mining costs*

\begin{tabular}{cccccc}
\hline Overall slope & \multicolumn{5}{c}{ Area of excavated blocks } \\
\cline { 2 - 6 } angle, $\alpha$ & Block 1 & Block 2 & Block 3 & Block 4 & Block 5 \\
\hline \multirow{2}{*}{40} & $2 \times(0.5 \times 19 \times 20)+$ & $2 \times(0.5 \times 19 \times 20)+$ & - & - & - \\
& $+(102 \times 20)=2420$ & $+(44 \times 20)=1260$ & & & - \\
45 & $2 \times(0.5 \times 15 \times 20)+$ & $2 \times(0.5 \times 15 \times 20)+$ & - & - & - \\
& $+(110 \times 20)=2500$ & $+(61 \times 20)=1520$ & & & - \\
50 & $2 \times(0.5 \times 10 \times 20)+$ & $2 \times(0.5 \times 10 \times 20)+$ & $2 \times(0.5 \times 10 \times 20)+$ & & \\
& $+(120 \times 20)=2600$ & $+(79 \times 20)=1780$ & $+(38 \times 20)=960$ & & \\
55 & $2 \times(0.5 \times 6 \times 20)+$ & $2 \times(0.5 \times 6 \times 20)+$ & $2 \times(0.5 \times 6 \times 20)+$ & $2 \times(0.5 \times 6 \times 20)+$ & \\
& $+(128 \times 20)=2680$ & $+(95 \times 20)=2020$ & $+(62 \times 20)=1360$ & $+(30 \times 20)=720$ & \\
60 & $2 \times(0.5 \times 4 \times 20)+$ & $2 \times(0.5 \times 4 \times 20)+$ & $2 \times(0.5 \times 4 \times 20)+$ & $2 \times(0.5 \times 4 \times 20)+$ & $2 \times(0.5 \times 4 \times 20)+$ \\
& $+(132 \times 20)=2720$ & $+(106 \times 20)=2200$ & $+(79 \times 20)=1660$ & $+(52 \times 20)=1120$ & $+(24 \times 20)=560$ \\
65 & $2 \times(0.5 \times 1 \times 20)+$ & $2 \times(0.5 \times 1 \times 20)+$ & $2 \times(0.5 \times 1 \times 20)+$ & $2 \times(0.5 \times 1 \times 20)+$ & $2 \times(0.5 \times 1 \times 20)+$ \\
& $+(138 \times 20)=2780$ & $+(115 \times 20)=2320$ & $+(92 \times 20)=1860$ & $+(69 \times 20)=1400$ & $+(47 \times 20)=960$ \\
70 & $2 \times(0.5 \times 0.71 \times 20)+$ & $2 \times(0.5 \times 0.71 \times 20)+$ & $2 \times(0.5 \times 0.71 \times 20)+$ & $2 \times(0.5 \times 0.71 \times 20)+$ & $2 \times(0.5 \times 0.71 \times 20)+$ \\
& $+(138.58 \times 20)=2785.8$ & $+(121.92 \times 20)=2452.6$ & $+(102 \times 20)=2054.20$ & $+(82 \times 20)=1654.20$ & $+(62 \times 20)=1254.20$ \\
\hline
\end{tabular}

Continuation of Table 4

\begin{tabular}{|c|c|c|c|c|c|}
\hline $\begin{array}{l}\text { Overall slope } \\
\text { angle, } \alpha\end{array}$ & Total area, $\mathrm{m}^{2}$ & Excavated depth, m & Volume, $\mathrm{m}^{3}$ & $\begin{array}{c}\text { Excavated tonnage } \\
\text { area } \times \gamma, \mathrm{t}\end{array}$ & $\begin{array}{c}\text { Cost } \\
\text { M\$ USD (\$2.29/ton) }\end{array}$ \\
\hline 40 & 3680 & 40 & 3680 & $3680 \times 2.51=9236.8$ & $\begin{array}{c}9236.8 \times 2.29 \times 10^{-6}= \\
=\mathrm{M} \$ 0.02115 \mathrm{USD}\end{array}$ \\
\hline 45 & 4020 & 40 & 4020 & $4020 \times 2.51=10090.2$ & $\begin{array}{c}10090.2 \times 2.29 \times 10^{-6}= \\
=\mathrm{M} \$ 0.02311 \mathrm{USD}\end{array}$ \\
\hline 50 & 5340 & 60 & 5340 & $5340 \times 2.51=13403.4$ & $\begin{array}{c}13403.4 \times 2.29 \times 10^{-6}= \\
=\text { M\$ } 0.0307 \text { USD }\end{array}$ \\
\hline 55 & 6780 & 80 & 6780 & $6780 \times 2.51=17017.8$ & $\begin{array}{c}17017.8 \times 2.29 \times 10^{-6}= \\
=\mathrm{M} \$ 0.03897 \mathrm{USD}\end{array}$ \\
\hline 60 & 8260 & 100 & 8260 & $8260 \times 2.51=20732.6$ & $\begin{array}{c}20732.6 \times 2.29 \times 10^{-6}= \\
=\mathrm{M} \$ 0.0475 \mathrm{USD}\end{array}$ \\
\hline 65 & 9320 & 100 & 9320 & $9320 \times 2.51=23393.2$ & $\begin{array}{c}23393.2 \times 2.29 \times 10^{-6}= \\
=\mathrm{M} \$ 0.0536 \mathrm{USD}\end{array}$ \\
\hline 70 & 10201 & 100 & 10201 & $10201 \times 2.51=25604.51$ & $\begin{array}{c}25604.51 \times 2.29 \times 10^{-6}= \\
=\mathrm{M} \$ 0.05863 \mathrm{USD}\end{array}$ \\
\hline
\end{tabular}

*Some assumptions have been made:

- cost of extraction of 1-ton of ore is assumed to equal \$2.29 USD;

- as 2D-analysis has been conducted, thus, the projected length of open pit in the third dimension is taken as unity;

- other mining costs such as hauling, hoisting, crushing, labour, supporting and upgrading are not considered here;

The costs may be changed according to market prices and ore type and therefore, net profit of ore can be practically estimated.

\section{ACKNOWLEDGEMENTS}

The authors acknowledge the support of Rocscience Inc. for getting a free two-week full-version of $\mathrm{RS}^{2 \mathrm{D}}$ (Rock-Soil two-dimensional finite-element analysis program). The authors are grateful for their support.

\section{REFERENCES}

Berisavljević, Z., Berisavljević, D., Čebašek, V., \& Rakić, D. (2015). Slope Stability Analyses Using Limit Equilibrium and Strength Reduction Methods. Journal of the Croatian Association of Civil Engineers, 67(10), 975-983. https://doi.org/10.14256/jce.1030.2014

Boeraeve, P. (2010). Introduction to the Finite Element Method (FEM). Liege, Belgium: Institut Gramme.

Brahma, B.P. (2009). Design of Stable Slope for Opencast Mines. Ph.D. Rourkela, India: Deemed University.

Brinkgreve, R.B.J., \& Bakker, H.L. (1991). Non-Linear Finite Element Analysis of Safety Factors. Proceeding of the $7^{\text {th }}$ International Conference on Computer Methods and Advances in Geomechanics, 1117-1122.

Bye, A., \& Bell, F. (2001). Stability Assessment and Slope Design at Sandsloot Open Pit, South Africa. International Journal of Rock Mechanics and Mining Sciences, 38(3), 449-466. https://doi.org/10.1016/s1365-1609(01)00014-4

Chatterjee, P., \& Elkadi, A. (2012). Strength Reduction Analysis. Amsterdam, The Netherlands: TNO DIANA BV.
Ching, R.K.H., \& Fredlund, D.G. (1983). Some Difficulties Associated with the Limit Equilibrium Method of Slices. Canadian Geotechnical Journal, (20), 661-672. https://doi.org/10.1139/t83-074

Fleurisson, J.A., \& Cojean, R., (2014). Error Reduction in Slope Stability Assessment. Surface Mining Methods, Technology and Systems, (1), 1-41.

Fredlund, D.G., \& Krahn, J. (1977). Comparison of Slope Stability Methods of Analysis. Canadian Geotechnical Journal, 14(3), 429-439. https://doi.org/10.1139/t77-045

GEO-SLOPE and SLOPE/W. (2010). Stability Modeling with SLOPE/W 2007.Version. Calgary, Alberta, Canada: Canada T2P 2Y5, GEO-SLOPE International Ltd.

Goodman, R.E. (1989). Introduction to Rock Mechanics. New York, United States: Wiley.

Hamade, T. (2013). Geotechnical Design of Tailings Dams - A Stochastic Analysis Approach. Ph.D. Montreal, Quebec, Canada: University of McGill.

Hammah, R.E., Yacoub, T.E., \& Corkum, B.C. (2005). The Shear Strength Reduction Method for the Generalized Hoek-Brown Criterion. In Alaska Rock 2005, The 40 th U.S. Symposium on Rock Mechanics (ARMA/USRMS 05-810). Anchorage, Alaska: American Rock Mechanics Association.

Hoek, E., \& Bray, J.W. (1981). Rock Slope Engineering. London, United Kingdom: Institution of Mining and Metallurgy. 
Hossain, M. (2011). Stability Analysis of Anchored Rock Slopes Against Plane Failure Subjected to Surcharge and Seismic Loads. Ph.D. Perth, Australia: Edith Cowan University.

Jaeger, J.C. (1971). Friction of Rocks and Stability of Rock Slopes. Géotechnique, 21(2), 970-134. https://doi.org/10.1680/geot.1971.21.2.97

Jiang, J., \& Cao, P. (2013). Stability Analysis and Optimal Excavation of an Open Pit Mine Slope. Electronic Journal of Geotechnical Engineering, (18), 5407-5419.

Krahn, J. (2003). The Limits of Limit Equilibrium Analyses. Canadian Geotechnical Journal, (40), 643-660. https://doi.org/10.1139/t03-024

Krahn, J. (2007). Limit Equilibrium, Strength Summation and Strength Reduction Methods for Assessing Slope stability. Rock Mechanics: Meeting Society's Challenges and Demands, 311-318. https://doi.org/10.1201/noe0415444019-c38

Kumar, V., \& Parkash, V. (2015). A Model Study of Slope Stability in Mines Situated in South India. Advances in Applied Science Research, 6(8), 82-90.

Li, A.J., Merifield, R.S., \& Lyamin, A.V. (2011). Effect of Rock Mass Disturbance on the Stability of Rock Slopes Using the Hoek-Brown Failure Criterion. Computers and Geotechnics, 38(4), 546-558. https://doi.org/10.1016/j.compgeo.2011.03.003

Maleki, M.R., Mahyar, M., \& Meshkabadi, K. (2011). Design of Overall Slope Angle and Analysis of Rock Slope Stability of Chadormalu Mine Using Empirical and Numerical Methods. Engineering, 3(9), 965-971. https://doi.org/10.4236/eng.2011.39119

Marndi, B. (2011). Stability of Slopes in Iron Ore Mines. PhD. Rourkela, India: Deemed University.
Morgenstern, N. R., \& Price, V.E. (1967). A Numerical Method for Solving the Equations of Stability of General Slip Surfaces. The Computer Journal, 9(4), 388-393. https://doi.org/10.1093/comjnl/9.4.388

Neupane, D. (2014). Comparison of Some FEM Codes in Static Analysis. Bachelor's Thesis. Hämeenlinna, Finland: Häme University of Applied Sciences.

Norton, R. (2006). Machine Design. Upper Saddle River, United States: Pearson Prentice Hall.

Potts, D.M., \& Zdravkovic, L. (1999). Finite Element Analysis in Geotechnical Engineering: Theory. London, United Kingdom: Thomas Telford. https://doi.org/10.1680/feaiget.27534

RocScience and Slide. (2011). Slide: $2 D$ Limit Equilibrium Slope Stability Analysis. [online]. Available at: https://www.cesdb.com

RocScience Inc. (2016). Rock and Soil 2-Dimensional Analysis Program. [online]. Available at: https://www.rocscience.com

Roosta, R., Sadaghiani, M., \& Pak, A. (2005). Strength Reduction Technique in Stability Analysis of Jointed Rock Slopes. International Journal of Civil Engineering, 3(3-4), 152-165.

Singh, V.K. (2006). Slope Stability Study for Optimum Design of an Opencast Project. Journal of Scientific \& Industrial Research, (65), 47-56.

Soren, K., Budi, G., \& Sen, P. (2014). Stability Analysis of Open Pit Slope by Finite Difference Method. International Journal of Research in Engineering and Technology, 3(5), 326-334. https://doi.org/10.15623/ijret.2014.0305062

Wyllie, D.C., \& Mah, C.W. (2004). Rock Slope Engineering. London, United Kingdom: Spon Press.

\section{ОЦІНКА СТІЙКОСТІ БОРТУ КАР'ЄРА ПРИ РІЗНИХ КУТАХ ЙОГО НАХИЛУ 3 ВИКОРИСТАННЯМ ЕЛЕМЕНТІВ АНАЛІЗУ РІЗНОГО ТИПУ}

\section{В.Р. Абделлах, М.М. Беблаві, М.Т. Мохамед}

Мета. Розробка методики для підбору оптимального кута нахилу борта кар'єру з видобутку мідно-нікелевих руд з урахуванням трьох головних чинників: безпека, продуктивність та витрати, а також перевірка точності чисельного аналізу при використанні елементів різного типу і порядку.

Методика. Побудовано серії двовимірних пружно-пластичних кінцево-елементних моделей (КЕМ) для різ-

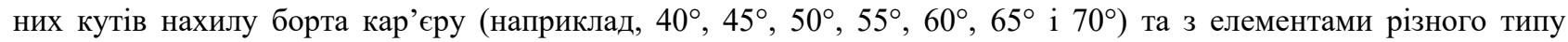
(3-вузловий трикутник $\left(T_{3}\right), 6$-вузловий трикутник $\left(T_{6}\right), 4$-вузловий чотирикутник $\left(Q_{4}\right)$ і 8 -вузловий чотирикутник $\left.\left(Q_{8}\right)\right)$. Чисельне моделювання виконано у програмному продукті Rock and Soil 2-Dimensional Analysis Program. B якості критерію руйнування прийнято критерій міцності Кулона-Мора.

Результати. Дослідження показали, що продуктивність шахти зростає зі збільшенням кута нахилу борта кар'єру; однак при цьому зменшується його стійкість, і навпаки, чим крутіше кут нахилу борта, тим менше коефіцієнт безпеки. Так, мінімальному значенню коефіцієнта безпеки відповідає найбільший кут нахилу $70^{\circ}$. Незважаючи на більш тривалі обчислення, аналіз показав, що точність моделювання зростає при використанні елементів високого порядку (8-вузлового чотирикутника і 6-вузлового трикутника).

Наукова новизна. Розроблено новий методичний підхід для застосування чисельного моделювання для оцінки стійкості бортів кар'єрів з точки зору граничного коефіцієнта зниження міцності або його еквівалентного коефіцієнта безпеки, загального зсуву схилів, продуктивності та витрат на видобуток.

Практична значимість. Дослідження доводять ефективність застосування чисельного моделювання для визначення доцільності витрат при різних кутах нахилу борта для забезпечення безпеки робіт. В результаті його застосування проектувальники кар'єрів зможуть заздалегідь спланувати оптимальний кут нахилу борта 3 урахуванням безпеки, продуктивності і витрат.

Ключові слова: стійкість борту, кар'єр, граничний коефіцієнт зниження міцності (ГКЗМ), метод скінченних елементів (МСЕ), чисельне моделювання, критерій міцності 


\title{
ОЦЕНКА УСТОЙЧИВОСТИ БОРТА КАРЬЕРА ПРИ РАЗЛИЧНЫХ УГЛАХ ЕГО НАКЛОНА С ИСПОЛЬЗОВАНИЕМ ЭЛЕМЕНТОВ АНАЛИЗА РАЗНОГО ТИПА
}

\author{
В.Р. Абделлах, М.М. Беблави, М.Т. Мохамед
}

Цель. Разработка методики для подбора оптимального угла наклона борта карьера по добыче медноникелевых руд с учетом трех главных факторов: безопасность, производительность и затраты, а также проверка точности численного анализа при использовании элементов различного типа и порядка.

Методика. Построены серии двумерных упругопластических конечно-элементных моделей (КЭМ) для разных углов наклона борта карьера (например, $40^{\circ}, 45^{\circ}, 50^{\circ}, 55^{\circ}, 60^{\circ}, 65^{\circ}$ и $70^{\circ}$ ) и с элементами разного типа (3-узловой треугольник $\left(T_{3}\right), 6$-узловой треугольник $\left(T_{6}\right), 4$-узловой четырехугольник $\left(Q_{4}\right)$ и 8 -узловой четырехугольник $\left.\left(Q_{8}\right)\right)$. Численное моделирование выполнено в программном продукте Rock and Soil 2-Dimensional Analysis Program. В качестве критерия разрушения принят критерий прочности Кулона-Мора.

Результаты. Исследования показали, что производительность шахты растет с увеличением угла наклона борта карьера, однако при этом уменьшается его устойчивость, и наоборот, чем круче угол наклона борта, тем меньше коэффициент безопасности. Так, минимальному значению коэффициента безопасности соответствует самый большой угол наклона $70^{\circ}$. Несмотря на более длительные вычисления, анализ показал, что точность моделирования возрастает при использовании элементов высокого порядка (8-узлового четырехугольника и 6-узлового треугольника).

Научная новизна. Разработан новый методический подход для применения численного моделирования для оценки устойчивости бортов карьеров с точки зрения предельного коэффициента снижения прочности или его эквивалентного коэффициента безопасности, общего смещения склонов, производительности и затрат на добычу.

Практическая значимость. Исследования доказывают эффективность применения численного моделирования для определения целесообразности затрат при различных углах наклона борта для обеспечения безопасности работ. В результате его применения проектировщики шахт смогут заранее спланировать оптимальный угол наклона борта с учетом безопасности, производительности и затрат.

Ключевые слова: устойчивость борта, карьер, предельный коэффициент снижения прочности (ПКСП), метод конечных элементов (МКЭ), численное моделирование, критерий прочности

\section{ARTICLE INFO}

Received: 23 January 2018

Accepted: 16 March 2018

Available online: 26 March 2018

\section{ABOUT AUTHORS}

Wael R. Abdellah, Doctor of Philosophy, Assistant Professor of the Mining and Metallurgical Engineering Department, University of Assiut, 71516, Assiut Governorate, Assiut, Egypt. E-mail: wre544@gmail.com

Mostafa M. Beblawy, Doctor of Philosophy, Professor of the Mining and Metallurgical Engineering Department, University of Assiut, 71516, Assiut Governorate, Assiut, Egypt. E-mail: mbeblawi@aun.edu.eg

Mostafa T. Mohamed, Doctor of Philosophy, Professor of the Mining and Metallurgical Engineering Department, University of Assiut, 71516, Assiut Governorate, Assiut, Egypt. E-mail: mostafa.amin@eng.au.edu.eg 